\title{
A Review of Elinor Mason's Ways to be Blameworthy
}

\author{
Andreas Brekke Carlsson ${ }^{1}$
}

Accepted: 30 May 2021 / Published online: 19 June 2021

(C) The Author(s) 2021

\begin{abstract}
In this review, I summarize Elinor Mason's Ways to be Blameworthy and raise some worries concerning three aspects of her book: her account of the knowledge condition on moral responsibility, her notion of blame and its justification as well as Mason's conception of extended blameworthiness.
\end{abstract}

Keywords Mason $\cdot$ Blame $\cdot$ Responsibility

Elinor Mason's Ways to be Blameworthy (2019) aims to explain the relationship between our concepts of rightness and wrongness and our concepts of praise- and blameworthiness. Although it is commonly agreed that there is some kind of connection between our deontic concepts and our responsibility concepts, the exact nature of this relationship is rarely investigated in detail. Mason's ambitious and important book brings together difficult questions that are typically discussed in isolation. The result is a pluralistic account, according to which there are three different kinds of blameworthiness.

According to Mason, there is a "responsibility constraint" on all concepts of rightness and wrongness. But it is not easy to spell out exactly what this connection consists in. Different concepts of rightness and wrongness correspond to praiseand blameworthiness in different ways. The more objective a theory is, the weaker the link to praise- and blameworthiness. In chapter 2, Mason develops an account of subjective obligation where the link between the praise- and blameworthiness is very close. An agent's subjective obligation, according to Mason, is to try to do well by Morality, where Morality is understood as the "true" morality. In order to do well by Morality the agent needs a sufficient (though not perfect) grasp of Morality.

I thank Anna Drożdżowicz, Leonhard Menges, and Elinor Mason for helpful comments on an earlier draft. For additional funding, I am grateful to Conceptlab, University of Oslo, (Grant No. 250654, Research Council of Norway).

Andreas Brekke Carlsson andreas.carlsson@inn.no

1 Department of Law, Philosophy and International Studies, Inland Norway University of Applied Sciences, Lillehammer, Norway 
"Trying to do well by morality is praiseworthy. Not trying hard enough or failing to try is blameworthy" (74).

Trying thus plays an important role in Mason's book and chapter 3 provides an account of this notion. Mason argues that trying is subject to a reflexivity requirement: trying to do well by Morality requires that one knows one is trying. This need not, however, amount to conscious awareness. The knowledge can be tacit, implicit, or in the background when the agent is acting. Trying, according to Mason, involves both a general outlook and attitudes, as well as taking the steps the agents believes most likely to result in doing well by Morality. Correspondingly, failing to try requires that the agent understands the standards of "true" Morality, and accepts that they apply to her.

In chapter 4, Mason argues that the notion of subjective obligation correlates with one kind of moral praise- and blameworthiness, what she calls "ordinary" praiseand blameworthiness. If an agent tries to do well by Morality, she is praiseworthy; if she fails to try, or does not try hard enough, she is blameworthy. The reflexivity requirement allows Mason to tread a middle path in the debate about the knowledge condition on blameworthiness. Mason argues that a grasp of Morality is necessary for ordinary praise- and blameworthiness. However, she does not think this grasp requires full awareness of the relevant moral facts. Background knowledge is sufficient.

In chapter 5, Mason contrasts ordinary praise and blame with detached praised and blame. Ordinary blame (and praise) is communicative. Drawing on Michael McKenna's (2012) theory of responsibility, Mason argues that we should see blame and praise as part of a conversation. Blame includes a demand that the wrongdoer recognizes their wrongdoing and feels remorse. Ordinary blame is directed towards members of the moral community who have a grasp on Morality. When such agents act wrongly, they do so by their own lights. This is why we are entitled to expect the acknowledgment of wrongdoing as well as remorse from the wrongdoer and why the communicated blame is felicitous. Detached blame, by contrast, is directed towards agents who do not have a grasp on Morality. They have not acted wrongly by their own lights, and blame towards them is not communicative. Detached blame goes beyond judgments of blameworthiness and can take the form of emotional reactions like disdain, repugnance or anger, or a modification of one's relationship with the wrongdoer.

Chapter 6 concerns excuses. According to objective accounts of moral rightness, there is a gap between acting wrongly and being blameworthy. After all, one might have an ordinary excuse: lack of control or ignorance. According to Mason's account of subjective wrongdoing, one acts wrongly if one fails to try to do well by Morality, given one's available knowledge and control. Violating one's subjective obligation thus leaves no room for ordinary excuses. Mason nevertheless claims that there can be mitigating factors that apply to those who act subjectively wrongly.

Mason also discusses exemptions from ordinary blameworthiness (Chapter 7). She argues that deep moral ignorance is sufficient for being outside the moral community. In such cases, only detached, non-communicative forms of blame are appropriate. Mason also argues that agents who understand Morality but lack the capacity to act otherwise might nevertheless be praise- or blameworthy. 
Chapter 8 develops a third form of blameworthiness, what Mason calls "extended blameworthiness." People sometimes do bad things inadvertently, or because of their own bad motives or implicit biases. They may nevertheless have tried hard to do well by Morality. In such cases the agent will not have acted subjectively wrongly and thus not be blameworthy in the ordinary sense. Mason argues that such agents can take responsibility by accepting blame from others and be willing to feel remorse for what they have done.

Ways to be Blameworthy is a rich and exciting book, full of thought provoking ideas. It connects several different debates in new ways and provides the reader with interesting and novel accounts of subjective obligations, the nature and conditions of blame and blameworthiness. It also provides a more sustained discussion of praise and praiseworthiness than is common in a literature where the focus typically has been on the negative side of responsibility. Given that the book is relatively short (213 pages), there are areas where one could wish for a more detailed development and defense of the main claims. In the remainder of this review, I will focus on one such area: Mason's account of blame- and blameworthiness.

An important claim in Mason's book is that violating a subjective obligation correlates with ordinary blameworthiness. If the agent acted wrongly, by her own lights, she is blameworthy. Although there might be mitigating circumstances, there is no room for excuses. However, a reader might wonder why this should be the case. Consider first Mason's account of the conditions of blameworthiness. The knowledge condition on blameworthiness has long been a contentious issue. Attributionists like Nomy Arpaly (2003), Elizabeth Harman (2011) and Angela Smith (2005) argue that agents who are morally ignorant can be blameworthy as long as their actions display a morally insufficient quality of will. The proponents of the "searchlight" view on the other hand, including Gideon Rosen (2004), Neil Levy (2011) and Michael Zimmerman (1997), argue that agents need to be fully aware of the wrong making features of their actions and of the fact that these actions are wrong. Only actions and omissions that either are, or can be traced back to, instances of cleareyed akrasia are blameworthy. The problem with attributionism is that it makes it too easy to be blameworthy; the problem with the searchlight view is that it makes it too hard. On the latter view, many if not most of our morally wrong actions will be excused. Mason's account of the conditions for ordinary blameworthiness avoids these two extremes. She argues that the knowledge requirement for ordinary blameworthiness is just the same as for failing to try: knowledge of Morality is necessary, but this knowledge can be in the background; it can be tacit or implicit. Mason argues that the relevant question is whether the agent should have known better (86). However, as she points out, the notion of 'should' is ambiguous. Whenever an agent acts wrongly, there is a sense in which she should have acted differently. If the "should have" attaches to an objective sense of rightness, this hardly settles the issue of blameworthiness. After all, the agent might have had an excuse for not having acted as she should have acted in the objective sense. Mason argues that the relevant notion of "should have" is subjective, in the sense that the agent herself would recognize that she should have been motivated differently or should have known. "She should have done things differently, because, by her own lights, she should have. So crucially, in not doing things differently, she is blameworthy" (89). Applied to 
the knowledge requirement, Mason thinks this subjective sense of should applies to agents who would have seen that their act was problematic if only they have thought about it a little longer, or tried a little harder (90). Such agents are blameworthy, according to Mason, because, they should have acted differently by their own lights.

One may worry that this reply does not properly engage with the argument for the searchlight view. Proponents of this view argue that we can only be directly blameworthy for things over which we have voluntary control. As long as our knowledge of Morality is merely background knowledge, we cannot use it when we are deliberating and choosing what to do. Consider Angela Smith's (2005) case of a person who forgets her friend's birthday. The fact that she would have easily remembered about the birthday if she wasn't so preoccupied, or if she were prompted, does not make it the case that she, in the moment of action, had voluntary control over whether she would call her friend or not. It seems that a proponent of the searchlight view could agree that agents who have background knowledge of Morality should have acted differently in the subjective sense, but deny that they are blameworthy for failing to act differently. Even if they should have acted differently by their own light, they nevertheless have an excuse for not doing so: they lacked the relevant kind of control necessary for being blameworthy.

One way to reply to this argument would be to adopt a less robust notion of blame. Proponents of the searchlight view are typically making a first order moral argument: blame is harmful, and no one deserves to be harmed for what they cannot control. If blame turns out not be harmful, this argument loses much of its appeal. Mason herself suggests this kind of reply: "In fact, I do not think that imposing suffering is an essential part of blame, so the burden on me to justify blame is lighter than on those who think that hostile attitudes are essential" (footnote 12, page 22).

Mason distinguishes her account of blame from punishment by noting that blame does not necessarily aim at suffering (though it may). But suffering does seem essential to her account of the blame conversation. Ordinary blame communicates an expectation that the wrongdoer recognizes her wrongdoing and feels remorse for what she has done. Accepting blame thus involves feeling remorse. Remorse is necessarily painful or unpleasant. This raises the question of how the pain of remorse is justified on Mason's account. In chapter 2, Mason notes that she is not claiming that agents who violate a subjective obligation deserve the suffering that goes along with blame. Rather, she wants to defend an account of what makes blame fitting. Mason does not explain exactly what she means by fittingness. The appropriateness, or fittingness of blame, on Mason's account, seems to depend on whether the communication of blame is conversationally felicitous or not. Ordinary blame is appropriately directed towards agents with a grasp of Morality; i.e. agents who have acted wrongly by their own lights. She writes: "What makes it felicitous as communication is that it reminds the agent of something she already knows" (106). However, one might wonder whether this provides a sufficient justification for the harm of the remorse that Mason takes to be an integral and appropriate part of a felicitous blame conversation. It seems uncontroversial that agents who have acted wrongly by their own lights can be expected to recognize their own wrongdoing. But it is less clear why they should feel remorse simply in virtue of having acted wrongly by their own lights. In cases where they only had background knowledge of Morality, for 
example, it seems that they could admit that they acted wrongly, but maintain, with Rosen, Zimmerman, and Levy, that their lack of conscious awareness provides them with an excuse.

Mason also argues that the blamer is normatively entitled to expect acceptance of blame and remorse "because that is part of what being part of the moral community involves. It is important to recognize that this is not a first order moral norm. [...] Rather, if [wrongdoers] want to carry on in good standing in the moral community, they ought to accept my blame. This is a broader hypothetical requirement-accepting blame, and engaging in blame exchanges is what we have to do if we want to be fully engaged in our moral community." (105). This sounds right, once it is established that agents who act subjectively wrongly ought to feel remorse. However, I don't think that Mason has yet provided this justification. Absent an independent justification, it seems that we can legitimately ask why membership in the moral community should require such agents to be pained by remorse.

Similar issues arise in Mason's account of extended blameworthiness. In chapter 8 , she argues that agents who are not blameworthy in the ordinary sense sometimes should take responsibility, by accepting the blame of others and show a willingness to feel remorse. This applies to situations where the agent tries to do well by Morality but acts wrongly, either inadvertently or because of a bad will or implicit bias. Mason illustrates extended blameworthiness with the example of Perdita who has inadvertently lost her friend's necklace. Mason stipulates that Perdita wasn't careless, and took her duties sufficiently seriously. There was no ill will; she simply forgot where she put the necklace. When blamed by her friend, Perdita could argue that the blame is misplaced. In a sense, she is correct. She is not blameworthy in the ordinary sense. However, Mason argues that Perdita should instead accept the blame, and allow herself to feel remorse. The "should" is not a moral "should". Rather, it is a hypothetical should, based on the requirement of relationships. If we want to take part in personal relationships, we should be willing to take responsibility. Mason points out that our relationships require that we are emotionally invested in them. By taking responsibility, Perdita acts as her relationship requires.

It wasn't obvious to me that our relationships require us to engage in the practice of extended blame conversations. Consider first the perspective of the blamer. If relationships can require the wrongdoer to take responsibility, it seems that relationships also can require the person being wronged to respond with blame and an expectation of remorse when people with whom one has a relationship make inadvertent mistakes. But this seems harsh to me. Arguably, there are other ways of responding, compatible with the requirements of relationships. Mason points out that to stop holding one's partner accountable is a sign that the relationship has dissolved and contrasts extended blame conversations with estrangement and alienation (201). However, there is an important difference between not engaging in blame conversations when one's partner is blameworthy in the ordinary sense, and not doing it when the partner is not blameworthy. It might be that Mason's account of taking blame should rather be understood as a conditional: if inadvertent wrongdoers are being blamed, then they should accept it. But if the relationship does not require blame in the first place, it is not obvious that the relationship requires the acceptance of this blame. The person being blamed might instead apologize, express sadness, 
and a willingness to compensate. Moreover, even if it turns out that relationships do require this kind of interaction, it does not mean that they ought to be like this. It seems to me that norms of relationships can be modified and negotiated.

An interesting objection that Mason herself discusses in this context is that her account may seem to justify the practice of taking responsibility by its consequences. If Perdita is not blameworthy in the ordinary sense, it seems that remorse would be unfitting. She has a relationship-based reason to feel remorse, but that would seem to be the wrong kind of reason. The right kind of reason would rather be that Perdita acted subjectively wrongly, which she, according to Mason, did not. Mason's response is that it can be fitting to feel remorse when our agency is ambiguous. Situations where agents try their best, but nevertheless act badly because of their bad motives or implicit biases, or inadvertent actions, are examples of ambiguous agency, according to Mason. On the one hand they are not deliberate and do not involve controlled exercise of our agency. On the other, such actions are plausibly our acts. "They spring from our psychology, our agency is not obviously blocked." (182).

It is tempting to read this as an appeal to epistemic humility. If one is uncertain about whether one is blameworthy, it will in many cases-especially in interpersonal relationships - make sense to err on the right side and behave as if one is blameworthy. But this is not what Mason has in mind. She emphasizes that these cases are not instances of ordinary blameworthiness and stipulates that Perdita and other agents who exemplify ambiguous agency, did not act subjectively wrongly. But this makes it difficult to understand Mason's reply. It seems that wrongdoing based on ambiguous agency either makes remorse fitting or not. If it does, agents like Perdita will be blameworthy in the ordinary sense. If it does not, then there is nothing that makes her remorse fitting and the wrong kind of reason.

Ways to be Blameworthy is clearly an important contribution to the literature on moral responsibility. Given limited space, in this review I have discussed only some of the many interesting and original ideas developed in Mason's book.

Funding Open access funding provided by Inland Norway University Of Applied Sciences.

Open Access This article is licensed under a Creative Commons Attribution 4.0 International License, which permits use, sharing, adaptation, distribution and reproduction in any medium or format, as long as you give appropriate credit to the original author(s) and the source, provide a link to the Creative Commons licence, and indicate if changes were made. The images or other third party material in this article are included in the article's Creative Commons licence, unless indicated otherwise in a credit line to the material. If material is not included in the article's Creative Commons licence and your intended use is not permitted by statutory regulation or exceeds the permitted use, you will need to obtain permission directly from the copyright holder. To view a copy of this licence, visit http://creativecommons.org/licen ses/by/4.0/.

\section{References}

Arpaly, N. (2003). Unprincipled virtue. Oxford University Press. 
Harman, E. (2011). Does moral ignorance exculpate?. Ratio, 24(4), 443-468.

Levy, N. (2011). Hard luck. Oxford University Press

Mason, E. (2019) Ways to be blameworthy. Oxford University Press.

McKenna, M (2012). Conversation and responsibility. Oxford University Press

Rosen, G. (2004). Skepticism about moral responsibility. Philosophical perspectives, 18, 295-313.

Smith, A. M. (2005). Responsibility for attitudes: Activity and passivity in mental life. Ethics, 115(2), 236-271.

Zimmerman, M. J. (1997). Moral responsibility and ignorance. Ethics, 107(3), 410-426.

Publisher's Note Springer Nature remains neutral with regard to jurisdictional claims in published maps and institutional affiliations. 